\title{
EFFECT OF HYALURONIC ACID ON THE HEALING OF COLONIC ANASTOMOSIS IN RATS TREATED WITH CORTICOID
}

\section{EFEITO DO ÁCIDO HIALURÔNICO NA CICATRIZAÇÃO DE ANASTOMOSE DO CÓLON EM RATOS TRATADOS COM CORTICOIDE}

lana Campinho Braga de Araújo Lima ${ }^{1}$, Ítalo Medeiros Azevedo ${ }^{2}$, Keyla Borges Ferreira Rocha $^{3}$, Aldo Cunha Medeiros ${ }^{4}$

1. Graduate student, Medical School, Federal University of Rio Grande do Norte (UFRN), Natal-RN, Brazil.

2. PhD, Statistician, Department of Surgery, UFRN, Natal- RN, Brazil.

3. PhD, Associate Professor, Department of Pathology, UFRN, Natal- RN, Brazil.

4. PhD, Full Professor, Chairman, Nucleus of Experimental Surgery, UFRN, Natal-RN, Brazil.

Study performed at Department of Surgery, Federal University of Rio Grande do Norte (UFRN), Brazil.

Financial support: CNPq, Grant:311625/2018/5.

Conflicts of interest: None.

Address for correspondence: Department of Surgery, Federal University of do Rio Grande do Norte, Ave. Nilo Peçanha 620, Natal, RN, Brazil.

E-mail: cirurgex.ufrn@gmail.com.

Submitted: nov 16; accepted after revision, nov 25, 2020.

\section{ABSTRACT}

Objective: This study aimed at examining whether topical treatment of colon anastomosis with hyaluronic acid can influence the healing of colonic anastomosis in rats treated with systemic corticosteroid. Methods: Three groups of Wistar rats weighing $252 \pm 7 \mathrm{~g}$ were used, with six rats each, all submitted to anastomosis of the proximal colon: Group 1 - control rats, without treatment. Group 2 - rats treated with subcutaneous (s.c) corticosteroid, and topical application of $0.9 \%$ saline solution over the anastomosis. Group 3 - rats treated with corticosteroid s.c. and topical application of $0.4 \%$ hyaluronic acid $(10 \mathrm{mg} / \mathrm{ml})$ on colonic anastomosis. On the 7 th postoperative day, under anesthesia and laparotomy, the anastomosis site was subjected to the determination of rupture pressure. Then, samples containing the anastomosis site were resected and fixed in $10 \%$ buffered formaldehyde and embedded in paraffin. Masson $\mathrm{H}-$ $E$ and trichrome staining. Histometry evaluated the infiltration of inflammatory cells at the anastomosis site, using a numerical scale from 0 to 4 . Continuous variables were assessed using the Tukey test. Differences considered significant with $p<0.05$. Results: All animals survived the experiments. There were no abscesses, fistulas and macroscopically detectable dehiscences in the anastomosis site. The weight of the 
Effect of hyaluronic acid on the healing of colonic anastomosis in rats treated with corticoid Lima ICBA; et al

animals on the 7th postoperative day showed a statistically significant difference $(p<0.001)$ between the control $(253.6 \pm 6.3 \mathrm{~g})$ and corticoid $(221.6 \pm 15.4 \mathrm{~g})$ groups, as well as between the corticoid + . hyaluronic acid group $(257.8 \pm 9.7 \mathrm{~g})$ and corticosteroids (221.6 \pm 15.4$)$. There was no significant difference in the comparison between the control and corticoid + hyaluronic acid groups $(p>0.05)$. In the analysis of intraluminal pressure of colonic anastomosis, there was a statistically significant difference when comparing groups $1(286.8 \pm 9.9 \mathrm{mmHg})$ and $2(155 \pm 6.0 \mathrm{mmHg}), 1(286.8 \pm 9,9 \mathrm{mmHg})$ and 3 $(199.1 \pm 7.7)$ and $2(155 \pm 6.0 \mathrm{mmHg})$ and $3(199.1 \pm 7.7)$, with $p<0.001$ for all comparisons. Histopathological classification by the numerical scale: Group 1 - inflammatory response $(\mathrm{H}-\mathrm{E})$ grade 3 and collagen deposition by Masson Trichomic grade 1; Group 2 inflammatory response (H-E) grade 4 and deposition of collagen and fibroblasts by Masson's Trichrome grade1 $\backslash 2$; Group 3 - inflammatory response (H-E) grade 3 and deposition of collagen and fibroblasts by Masson's Trichrome grade $1 \backslash 2$. There was no significant difference between groups. Conclusion: The topical use of hyaluronic acid has a positive influence on the initial healing phase of colonic anastomosis in rats treated with systemic corticosteroid.

Key words: Healing. Colon. Anastomosis. Hyaluronic acid. Corticoid.

\section{RESUMO:}

Objetivo: Estudo com o objetivo de examinar se o tratamento tópico de anastomoses do cólon com ácido hialurônico pode influir positivamente a cicatrização das anastomoses colônicas em ratos tratados com corticoide sistêmico. Métodos: Foram usados três grupos de ratos Wistar pesando $252 \pm 7 \mathrm{~g}$, com seis ratos cada, todos submetidos a anastomose do cólon proximal: Grupo 1 - ratos controle, sem tratamento. Grupo 2 - ratos tratados com corticoide subcutâneo (s.c.), com aplicação tópica de solução salina $0,9 \%$ sobre as anastomoses. Grupo 3 - ratos tratados com corticoide s.c. e aplicação tópica de ácido hialurônico 0,4\% $(10 \mathrm{mg} / \mathrm{ml})$ sobre as anastomoses colônicas. No 70 dia pós-operatório, sob anestesia e laparotomia, o local da anastomose foi submetido à determinação da pressão de ruptura. Em seguida, amostras contendo o local da anastomose foram ressecadas e fixadas em formaldeído tamponado a $10 \%$ e embebidas em parafina. Coloração H-E e tricrômico de Masson. A histometria avaliou a infiltração de células inflamatórias no sítio da anastomose, usando uma escala numérica de 0 a 4 . As variáveis contínuas foram avaliadas pelo teste de Tukey. Diferenças consideradas significativas com $p<0,05$. Resultados: Todos os animais sobreviveram aos experimentos. Não houve presença de abscessos, fístulas e deiscências macroscopicamente detectáveis na zona de anastomose. O peso dos animais no 70 dia pós-operatório mostrou diferença estatisticamente significativa $(p<0,001)$ entre os grupos controle $(253,6 \pm 6,3 \mathrm{~g})$ e corticoide $(221,6 \pm 15,4 \mathrm{~g})$, bem como entre os grupos corticoide+ ácido hialurônico $(257,8 \pm 9,7 \mathrm{~g})$ e corticoide $(221,6 \pm 15,4)$. Não houve diferença significativa na comparação entre os grupos controle e corticoide + ácido 
Effect of hyaluronic acid on the healing of colonic anastomosis in rats treated with corticoid Lima ICBA; et al

hialurônico $(p>0,05)$. Na análise da pressão intraluminal das anastomoses colônicas, houve diferença estatisticamente significativa quando feita a comparação entre os grupos $1(286,8 \pm 9,9 \mathrm{mmHg})$ e $2(155 \pm 6,0 \mathrm{mmHg}), 1(286,8 \pm 9,9 \mathrm{mmHg})$ e $3(199,1 \pm 7,7)$ e

$2(155 \pm 6,0 \mathrm{mmHg})$ e $3(199,1 \pm 7,7)$, sendo $\mathrm{p}<0,001$ para todas as comparações. A classificação histopatológica pela escala numérica: Grupo 1 - resposta inflamatória (HE) grau 3 e deposição de colágeno pelo Tricômico de Masson grau 1; Grupo 2 - resposta inflamatória (H-E) grau 4 e deposição de colágeno e fibroblastos pelo Tricrômico de Masson grau1 $\backslash 2$; Grupo 3 - resposta inflamatória (H-E) grau 3 e deposição de colágeno e fibroblastos pelo Tricrômico de Masson grau 1\2. Não houve diferença significativa entre os grupos. Conclusão: O uso tópico de ácido hialurônico influi positivamente na fase inicial da cicatrização de anastomoses colônicas em ratos tratados com corticoide sistêmico.

Palavras-Chave: Cicatrização. Cólon. Anastomose. Ácido hialurônico. Corticoide.

\section{INTRODUCTION}

Hyaluronic acid ( $\mathrm{HA})$ is a polysaccharide that belongs to the family of glycosaminoglycans and consists of two sugars, glucuronic acid and $\mathrm{N}$-acetylglucosamine. HA exists as a high molecular weight in the synovial liquid that involves joints, cartilage and tissues of the eye and skin. It is one of the main components of the extracellular matrix of scar tissue in the fetus, which heals without any sequelae or residual marks on the skin in the postoperative period. An experimental study was able to reduce alcohol-induced fibrogenesis in vitro in normal human hepatocytes ${ }^{1}$ and also induce in vitro the healing of human epithelial cells using HA preparation obtained from human umbilical cord².

HA has been used in animal models. It was used to enhance wound healing in full-thickness surgical wound models ${ }^{3,4}$. Facilitated re-epithelialization, led to the formation of tissue with good elasticity and increased microvascular density ${ }^{5,6}$. It showed promising results for the repair of connective tissue in the repair of tendons and cartilage in models using rabbits ${ }^{3}$. Bone repair was improved in rats and rabbit models ${ }^{7}$. Zachetta et al studied bone healing and observed that the best results obtained in the control group can be partially explained by the transport of HA components in the blood, spreading them evenly and suggesting systemic activity ${ }^{8}$. The use of chitosanhyaluronan/fibroin in cardiac lesions improved cardiac repair in a rat model of myocardial infarction. Neovascularization was widely distributed in the myocardium of regions of left ventricular infarction in the treatment group, being absent in the control, probably due to the greater secretion of paracrine factors in the regions of myocardial infarction in the left ventricle in the group treated with $\mathrm{HA}$, in comparison with the control ${ }^{9}$. 
Effect of hyaluronic acid on the healing of colonic anastomosis in rats treated with corticoid Lima ICBA; et al

Prolonged psychological stress delays the healing of wounds in humans, including chronic stress, since there is considerable systemic release of corticosteroids ${ }^{10}$. Likewise, stress induced in mice delays the healing of wounds, and also negatively affects the recovery of superficial injuries on human skin ${ }^{11,12}$. A commonly proposed mechanism to explain stress-induced delays in wound healing is the stimulation of aberrant "neuroimmunoendocrine" mechanisms, driven by a variety of biological mediators. One of them is corticoid12. The presence of corticosteroids in the tissues can contribute to delays in wound healing, as well as stress, confirming that the increased systemic corticoid causes delayed healing of full-thickness wounds. Systemic blockade of corticosteroid production restores the kinetics of normal healing ${ }^{13,14}$.

Relevant information is the fact that wounds resulting from fetal surgery have perfect healing, without scars. Fetal wounds are unique in their ability to heal quickly without forming residual scars. Amniotic fluid, rich in nutrients, growth factors and hyaluronic acid, surrounds the fetus and is essential for the healing of fetal wounds. The healing properties of fetal wounds may be the result of high concentrations of hyaluronic acid in the healing tissues ${ }^{15}$.

Based on the data above, we elaborated the hypothesis that the topical treatment of colon anastomosis with hyaluronic acid can influence the healing of anastomosis in rats treated with systemic corticosteroids

\section{METHODS}

Wistar rats, 3 to 4 months of age, weighing $252 \pm 7 \mathrm{~g}$, were used. This protocol was submitted to the appreciation and approved by the Ethics Committee on the Use of Animals of the HUOL (CEUA / HUOL) according to the protocol no 07/2018. The Wistar rats were kept in individual polypropylene cages with $12 \mathrm{~h}$ light-dark cycles. Initially, the animals went through a 7-day acclimatization period at the Experimental Surgery Nucleus (from the Federal University of Rio Grande do Norte-UFRN), with ad libitum access to water and food for rats (Presence ${ }^{\circledR}$ ). The care in the use of animals followed the Brazilian Legislation for the scientific use of animals (Law $n$ ㅇ 11794/2008).

The animals were randomly selected and allocated to 3 groups, with six rats each, all of which had an anastomosis of the proximal colon. Group 1 - control rats, without treatment. The other rats were treated with subcutaneous use of dexamethasone 10 $\mathrm{mg} / \mathrm{kg}$ immediately before the anastomosis. Group 2 - rats were treated with topical application of $0.9 \%$ saline solution over anastomosis. Group 3 - rats treated with topical application of $0.4 \%$ hyaluronic acid $(10 \mathrm{mg} / \mathrm{ml})$ over colonic anastomosis.

\section{Surgical procedures}

The day before the operations, the animals were kept on a liquid diet. To perform the surgical procedure, the rats were anesthetized with intraperitoneal (i.p.) ketamine 
Effect of hyaluronic acid on the healing of colonic anastomosis in rats treated with corticoid Lima ICBA; et al

$70 \mathrm{mg} / \mathrm{kg}$ of weight, associated with xylazine at a dose of $7 \mathrm{mg} / \mathrm{kg}$ of weight and operated under aseptic technique.

The animals were fixed on the operating table in supine position, and epilation of the skin of the abdomen as well as antisepsis with $70 \%$ alcohol were performed. A median laparotomy of $3 \mathrm{~cm}$ was performed and the proximal colon was transected $3 \mathrm{~cm}$ after the cecum. Intestinal continuity was restored by end-to-end anastomosis ( 8 stitches of sutures interrupted using 6-0 polypropylene, with atraumatic needle). After the anastomosis was completed, in group III animals $0.4 \%$ hyaluronic acid was applied around the anastomosis on entire circumference, waiting 10 minutes for its absorption. After operations, postoperative pain was controlled with analgesia (meperidine i.m. at a dose of $10 \mathrm{mg} / \mathrm{kg}$, at daily dose for the first 3 days). The animals were observed in individual cages, received only water in the first 24 hours after surgery, followed by a solid diet. They were weighed before the operation and at the moment of euthanasia (thiopental $100 \mathrm{mg} / \mathrm{kg}$ i.p.) which occurred on the 7th day of observation. The animals were operated with aseptic technique and during the observation period they were kept in the postoperative control room at the Nucleus of Experimental Surgery.

The site of each anastomosis was assessed after 7 days. Anastomosis were classified on a scale of 1 to 3 ; (1) non-fistula (2) small abscess at the anastomosis site (3) abscess at the anastomosis site, or (4) complete dehiscence with peritonitis/death from fecal peritonitis. All surgical procedures were performed by an experienced surgeon (ACM).

\section{Determination of rupture pressure}

On the 7th postoperative day, after anesthesia and laparotomy, a polyethylene catheter with a diameter of $3 \mathrm{~mm}$ was inserted through a small transverse incision in the colon, $3 \mathrm{~cm}$ upstream in the colon anastomosis, with ligation using a 2-0 cotton thread to seal the colon/catheter set. The downstream side of the anastomosis was ligated with 2-0 cotton at $3 \mathrm{~cm}$ from the anastomosis. The catheter was connected to a continuous flow of oxygen under pressure, interspersed with a digital manometer (Handy Manometer PG-100B; Copal Electronics, Tokyo, Japan). The abdominal cavity was filled with saline solution. The rupture pressure of the anastomosis was measured (in $\mathrm{mmHg}$ ) as the intraluminal pressure sufficient for air leakage and bubbling through the anastomosis observed in the water seal.

\section{Histopathological evaluation}

After measuring the burst pressure, the samples containing the anastomosis were resected and fixed in a $10 \%$ buffered formaldehyde solution for 48 hours and embedded in paraffin. Sections $(5 \mu \mathrm{m})$ were cut and stained with Masson's trichrome and hematoxylin-eosin (H-E). For the histological classification scale, the infiltration of inflammatory cells (ie, lymphocytes, plasmocytes and polymorphonuclear leukocytes) 
Effect of hyaluronic acid on the healing of colonic anastomosis in rats treated with corticoid Lima ICBA; et al

and fibroblasts at the anastomosis site was evaluated, using the modified Ehrlich and Hunt numerical scale, from 0 to 4: $0=$ no evidence, $1=$ occasional evidence, $2=$ moderate evidence, $3=$ abundant evidence and $4=$ diffuse cells16. Collagen density, collagen deposition at the anastomosis site were assessed using the same scale. The sections were analyzed using an Olympus BX51 optical microscope, with a 100X magnification.. All evaluations were conducted by a pathologist researcher blind to the experimental groups.

\section{Statistical analysis}

All values were expressed as mean \pm standard deviation (SD). Continuous variables were determined by the Tukey test. The analyzes were paired and a value of $p<0.05$ was considered statistically significant. Statistical analyzes were performed using the BioEstat 5.0 software.

\section{RESULTS}

All animals survived the experiments. The classification of the anastomosis according to the graduation previously established in the methodology was not performed due to lack of data, as the presence of abscesses, fistulas and dehiscences in the area of the anastomosis. Macroscopically detectable lesions did not occur in any groups.

\section{Weight of the animals}

The weight of the animals on the 7th postoperative day showed a statistically significant difference $(p<0.001)$ between the control $(253.6 \pm 6.3 \mathrm{~g})$ and corticoid (221.6 $\pm 15.4 \mathrm{~g})$ groups, as well as between the corticoid + hyaluronic acid $(257.8 \pm 9.7 \mathrm{~g})$ and corticosteroids $(221.6 \pm 15.4)$ groups. There was no significant difference in the comparison between the control and corticoid+hyaluronic acid groups ( $p>0.05)$.

\section{Intraluminal pressure}

The determination of the intraluminal pressure of the colonic anastomosis demonstrated that there was a statistically significant difference when the control group $(286.8 \pm 9.9 \mathrm{mmHg}$ ) was compared with corticosteroid group $(155 \pm 6.0 \mathrm{mmHg})$, control group $(286.8 \pm 9,9 \mathrm{mmHg})$ with corticoid + acid. hyaluronic group(199.1 \pm 7.7$)$ and corticoid $(155 \pm 6.0 \mathrm{mmHg})$ with corticoid + hyaluronic acid $(199.1 \pm 7.7)$. The $p$-value for all comparisons was $\mathrm{p}<0.001$.

\section{Histopathological}

The healing process showed no significant difference between groups. Collagen deposition was present in a tenuous and delicate way in the three groups. However, the presence of granulation tissue and number of fibroblasts was more evident in the group 
Effect of hyaluronic acid on the healing of colonic anastomosis in rats treated with corticoid Lima ICBA; et al

whose animals were treated with corticoid and hyaluronic acid. The inflammatory response was more intense in the group treated with corticosteroid, with the presence of microscopic abscesses, mucosal ulcerations and serositis. The transmural response was evident and some animals showed a granulomatous response to foreign body. Emphysematous tissue lesions were observed in animals of the three groups.

In the control group, the histopathological findings using the Ehrlich and Hunt numerical scale reached grade 3 for the inflammatory response (H-E) and collagen deposition by Masson's Trichrome grade 1. (Total scores, 4). Figure 1.

In the corticoid group, the numerical classification Ehrlich and Hunt reached an inflammatory response (H-E) grade 4 and deposition of collagen and fibroblasts by Masson's Trichrome grade 1. (Total scores, 5). Figure 2.

In the corticoid + hyaluronic acid group the histopathological findings using the Ehrlich and Hunt numerical scale characterized an inflammatory response $(\mathrm{H}-\mathrm{E})$ grade 3 and deposition of collagen and fibroblasts by grade 2. (Total scores, 5). Figure 3.

In this item there was no significant difference between the 3 groups.

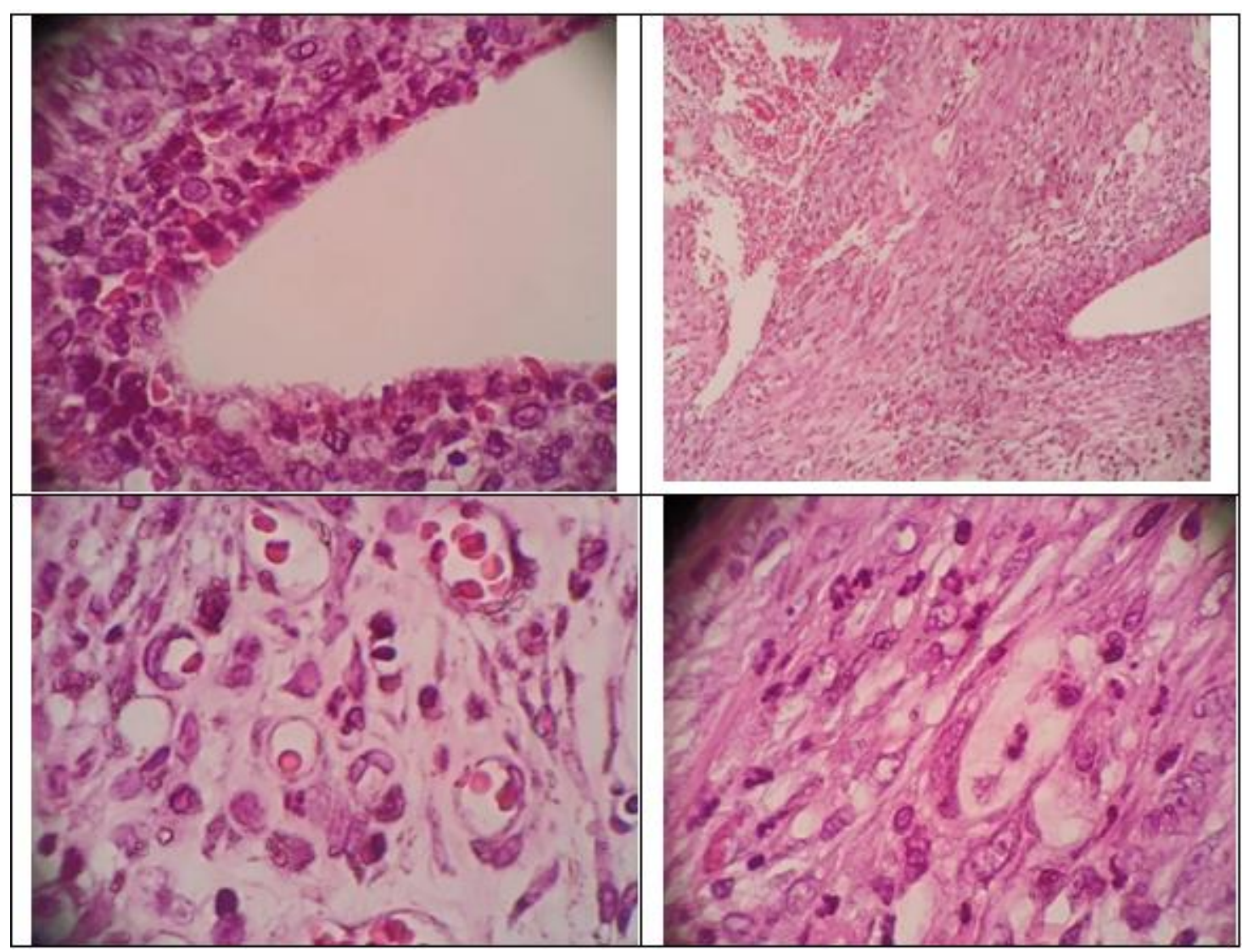

Figure 1: CONTROL GROUP (1): Photomicrographs of this group showing acute transmural chronic inflammatory process, with ulceration of the mucosa, formation of granulation tissue, serositis and outline of fistulous path. In two animals, an emphysematous lesion was observed in the intestinal wall. Presence of a giant cell reaction to a foreign body (suture) in the intestinal wall. H-E stain. 
Effect of hyaluronic acid on the healing of colonic anastomosis in rats treated with corticoid Lima ICBA; et al

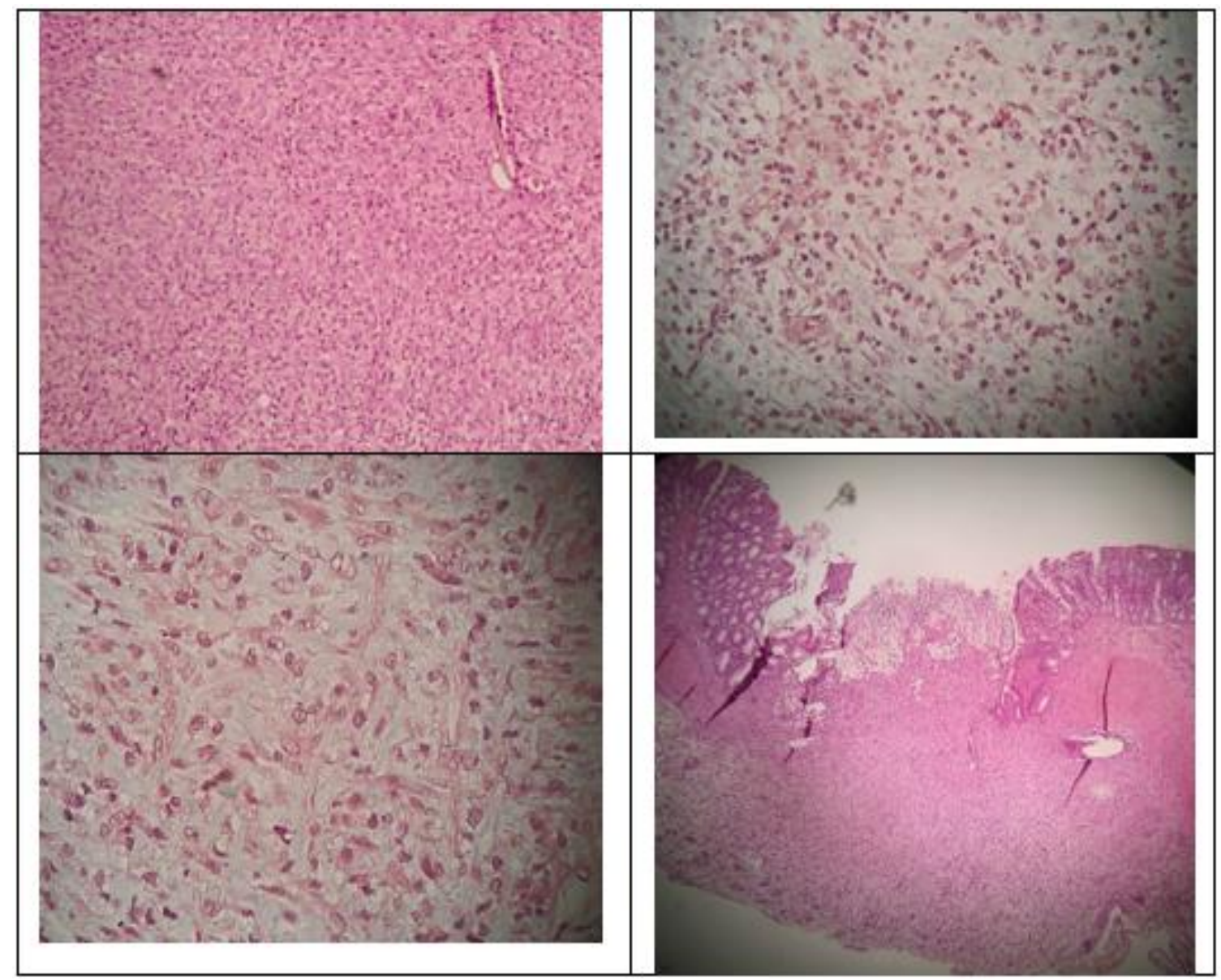

Figure 2: CORTICOID GROUP (2): Representative figures showing an acute transmural chronic inflammatory process, with ulceration of the mucosa, granulation tissue, areas of abscess and serositis. Tissue emphysema area. Presence of a giant cell reaction to a foreign body in the intestinal wall. $\mathrm{H}-\mathrm{E}$. 

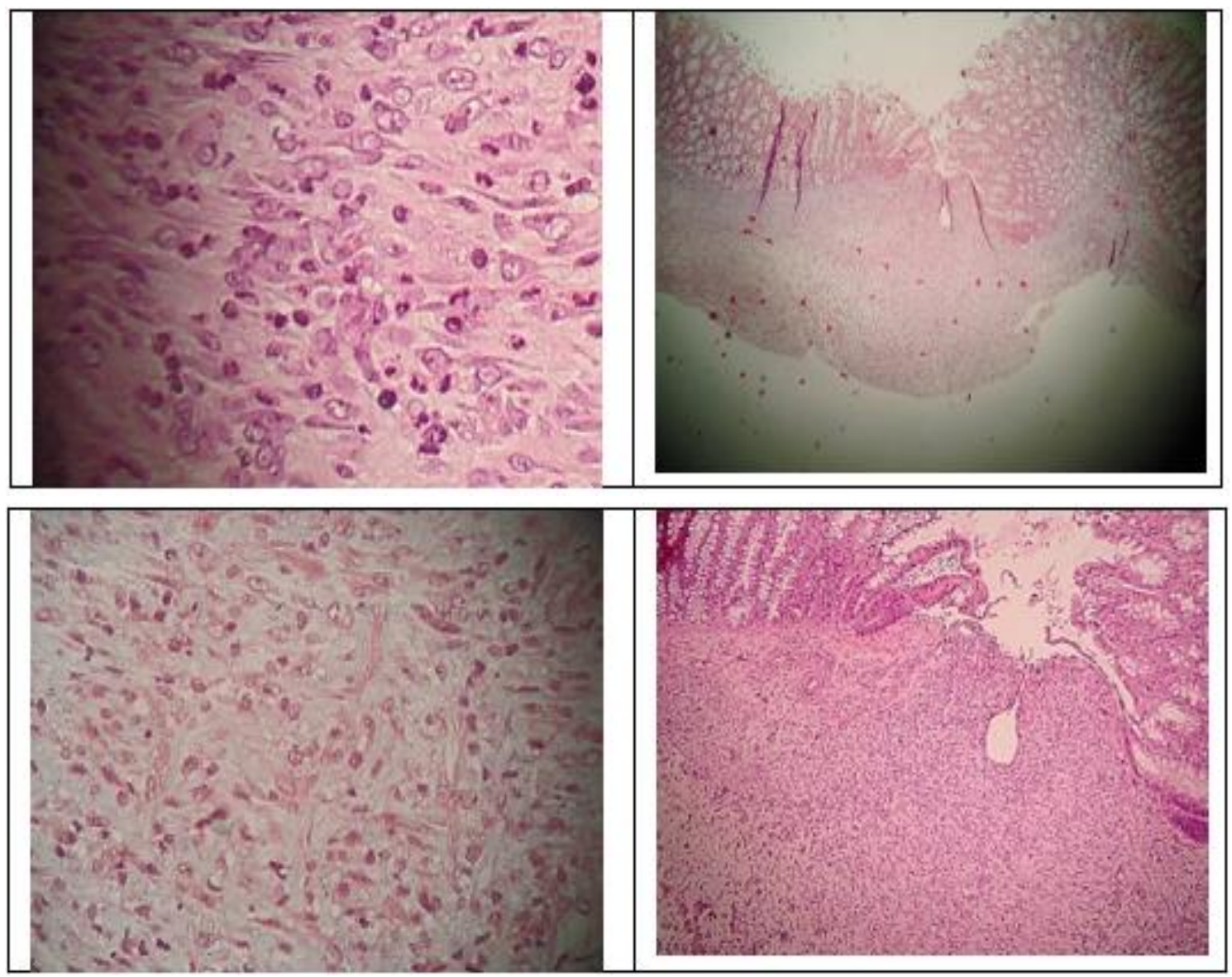

Figure 3: CORTICOID + HYALURONIC ACID GROUP (3): Representative images of an acute transmural chronic inflammatory process, with ulceration of the mucosa, granulation tissue, areas of abscess and serositis. Presence of a giant cell reaction to a foreign body in the intestinal wall. Large number of young fibroblasts, great angiogenesis. H-E.

\section{DISCUSSION}

Healing is a complex process that can be divided into three phases: inflammation, proliferation and remodeling. The inflammatory phase lasts for approximately 72 hours and the accumulation of neutrophils and monocytes occur in it ${ }^{17}$. The proliferative phase begins in the first 48 hours and can persist until the 14th day after injury, being responsible for angiogenesis, fibroplasia, formation of collagen, granulation tissue and re-epithelization ${ }^{18}$. Finally, in the remodeling phase, changes in the extracellular matrix occur and collagen matures, so that the maximum resistance of the wound to traction is reached in this phase ${ }^{17,18 .}$

Glucocorticoids appear to interfere in the inflammatory and proliferative phases of healing, resulting in reduced inflammatory cell infiltration and less fibroplasia, angiogenesis and collagen deposition ${ }^{19}$. Baca et all conducted a study with Spraque Dawley rats and found out that the use of corticosteroids impaired the healing of colonic anastomosis when used for long term and for short term, however, the results were 
Effect of hyaluronic acid on the healing of colonic anastomosis in rats treated with corticoid Lima ICBA; et al

worse in rats treated with high-dose corticosteroids for long term ${ }^{20}$. It was also observed that mice treated with hydrocortisone had reduced body weight variation and skin scars with less resistance in the first week after the injury when compared to mice that did not receive hydrocortisone ${ }^{21}$.

Hyaluronic acid interferes with the healing process by promoting the migration and differentiation of epithelial cells, which positively influences angiogenesis and collagen deposition ${ }^{22}$. These findings were observed in our study.

Traction and tension methods are considered the best parameters for assessing wound healing ${ }^{23}$. In this study, rupture pressure measurement revealed that the application of hyaluronic acid had a beneficial effect on the healing of colonic anastomosis in rats treated with systemic corticosteroids, since the rupture pressure value was lower in the group that received dexamethasone (group 2) when compared to the control and corticoid + hyaluronic acid groups.

The histopathological analysis did not show significant differences in the healing processes between the groups, however, it is noteworthy that the presence of granulation tissue and the number of fibroblasts was more evident in group 3 (corticoid + hyaluronic acid). A similar result was found in the study carried out by Baca et al, in which the histopathological comparison of the lesions found no important differences between the group treated with high doses of corticosteroids for a short term and the group that did not receive corticosteroids ${ }^{20}$.

This study has limitations regarding the observation time of the animals. Previous results showed the positive interference of $\mathrm{HA}$ in wound healing at various times of observation, and this distinction was not made in the study ${ }^{24,25}$. In addition, it was observed in another experimental study that the skin healing process became similar between mice that received hydrocortisone and those that did not receive it after the 14-day injury period ${ }^{21}$. Therefore, the positive result of the use of HA in the healing of colonic anastomosis in rats treated with systemic corticosteroids, evidenced in this study, was shown to be restricted to the first week after the procedure, as there were no analyzes of healing after this period. This fact does not invalidate the relevance of the results obtained, as it is in the first postoperative week that severe complications in anastomosis, such as fistulas and dehiscences, tend to occur.

\section{CONCLUSION}

In conclusion, treatment with levamisole resulted in better clinical and laboratory results in rats with abdominal sepsis when compared with peritoneal lavage and control. These results may have clinical implications, as it points to a possible use of this drug as a new adjuvant perspective for the control of abdominal sepsis. 
Effect of hyaluronic acid on the healing of colonic anastomosis in rats treated with corticoid Lima ICBA; et al

\section{REFERENCES}

1. Neuman MG, Nanau RM, Oruña L, Coto G. In vitro anti-inflammatory effects of hyaluronic acid in ethanol-induced damage in skin cells. J Pharm Pharm Sci. 2011;14:425-37.

2. Neuman MG, Oruña L, Coto G, Lago G, Nanau R, Vincent M. Hyaluronic acid signals for repair in ethanol-induced apoptosis in skin cells in vitro. Clin Biochem. 2010;43:822-6.

3. Oryan A, Moshiri A, Meimandi Parizi AH, Raayat Jahromi A. Repeated administration of exogenous Sodium-hyaluronate improved tendon healing in an in vivo transection model. J Tissue Viability. 2012;21:88-102.

4. Tuncay I, Erkocak OF, Acar MA, Toy $\mathrm{H}$. The effect of hyaluronan combined with microfracture on the treatment of chondral defects: an experimental study in a rabbit model. Eur J Orthop Surg Traumatol. 2013;23:753-8.

5. Zhao JY, Chai JK, Song HF, Zhang J, Xu MH, Liang YD. Influence of hyaluronic acid on wound healing using composite porcine acellular dermal matrix grafts and autologous skin in rabbits. Int Wound J. 2013;10:562-72.

6. Shimizu N, Ishida D, Yamamoto A, Kuroyanagi M, Kuroyanagi Y. Development of a functional wound dressing composed of hyaluronic acid spongy sheet containing bioactive components: evaluation of wound healing potential in animal tests. J Biomater Sci Polym Ed. 2014;25:1278-91.

7. Chen $Q$, Sun $G$, Wang $Y$, Zhong $W$, Shu $X Z$. The evaluation of two new hyaluronan hydrogels as nasal dressing in the rabbit maxillary sinus. Am J Rhinol Allergy. 2012;26:152-6.

8. Zanchetta P, Lagarde N, Uguen A, Marcorelles P. Mixture of hyaluronic acid, chondroitin 6 sulphate and dermatan sulphate used to completely regenerate bone in rat critical size defect model. J Craniomaxillofac Surg. 2012; 40:783-7.

9. Chi NH, Yang MC, Chung TW, Chou NK, Wang SS. Cardiac repair using chitosanhyaluronan/silk fibroin patches in a rat heart model with myocardial infarction. Carbohydr Polym. 2013;92:591-7.

10. Kiecolt-Glaser JK, Marucha PT, Malarkey WB, Mercado AM, Glaser R. Slowing of wound healing by psychological stress. Lancet. 1995;346:1194-6.

11. Altemus M, Rao B, Dhabhar FS, Ding W, Granstein RD. Stress-induced changes in skin barrier function in healthy women. J Invest Dermatol. 2001; 117:309-17.

12. Garg A, Chren MM, Sands LP, Matsui MS, Marenus KD, Feingold KR, et al. Psychological stress perturbs epidermal permeability barrier homeostasis: implications for the pathogenesis of stressassociated skin disorders. Arch Dermatol. 2001;137:53-9.

13. Slominski A, Zbytek B, Zmijewski M, Slominski RM, Kauser S, Wortsman J, et al. Corticotropin releasing hormone and the skin. Front Biosci. 2006;11:2230-48. 
Effect of hyaluronic acid on the healing of colonic anastomosis in rats treated with corticoid Lima ICBA; et al

14. Youm JK, Park K, Uchida Y, Chan A, Mauro TM, Holleran WM, Elias PM. Local blockade of glucocorticoid activation reverses stress- and glucocorticoid-induced delays in cutaneous wound healing. Wound Repair Regen. 2013;21(5):715-22.

15. Nyman E, Huss F, Nyman T, Junker J, Kratz G. Hyaluronic acid, an important factor in the wound healing properties of amniotic fluid: in vitro studies of reepithelialisation in human skin wounds. J Plast Surg Hand Surg. 2013;47(2):89-92.

16. Ehrlich, H. P., Trarver, H. \& Hunt, T. K. Efects of vitamin A and glucocorticoids upon infammation and collagen synthesis. Ann Surg. 1973;177:222-7.

17. Wang, Peng-Hui; Huang, Ben-Shian; Horng, Huann-Cheng; Yeh, Chang-Ching; Chen, Yi-Jen. Wound healing. J Chin Med Ass. 2018;81:94-101.

18. Gonzalez ACO, Costa TF, Andrade ZA, Medrado ARAP. Wound healing - A literature review. An Bras Dermatol. 2016:91:614-20.

19. Zinder R, Cooley R, Vlad LG, Molnar JA. Vitamin A and wound healing. Nutr Clin Practice. 2019;34:839-49.

20. Baca B, Ozben V, Boler DE, Onur E, Hamzaoglu I, Karahasanoglu T, Erdamar S, Atukeren $P$, Dirican A. Effect of corticosteroid dose and duration of administration on colonic anastomosis. Inflamm Bowel Dis.2010;16:2162-7.

21. Alberti LR, Vasconcellos LS, Petroianu A. Influence of local or systemic corticosteroids on skin wound healing resistance. Acta Cir Bras. 2012;27:295-9.

22. Hussain Z, Thu HE, Katas H, Bukhari SNA. Hyaluronic Acid-Based Biomaterials: a versatile and smart approach to tissue regeneration and treating traumatic, surgical, and chronic wounds. Polymer Rev. 2017;57:594-630.

23. Campos ACL, Borges-Branco A. Groth AK. Cicatrização de feridas. Arq Bras Cir Dig. 2007;20:51-8.

24. Damodarasamy M, Johnson RS, Bentov I, Maccoss MJ, Vernon RB, Reed MJ. Hyaluronan enhances wound repair and increases collagen III in aged dermal wounds. Wound Repair Reg. 2014;22:521-6.

25. Neuman MG, Nanau, Radu M, Oruña-Sanchez L, Coto G. Hyaluronic acid and wound healing. J Pharm Pharmaceut Sci.2015;18:53-60. 